\title{
LIPC wt Allele
}

National Cancer Institute

\section{Source}

National Cancer Institute. LIPC wt Allele. NCI Thesaurus. Code C82870.

Human LIPC wild-type allele is located within 15q21-q23 and is approximately $158 \mathrm{~kb}$ in length. This allele, which encodes hepatic triacylglycerol lipase protein, plays a role in lipid metabolism. Aberrant expression of the gene is associated with hyperlipidemia. 